\title{
Research on Innovation and Entrepreneurship of Electronic Communication Major in Local Undergraduate Colleges
}

\author{
Xiping Ma \\ School of electrical and information engineering \\ Beihua University \\ Jilin, China \\ E-mail:476036346@qq.com
}

\author{
Zhongli Wang* \\ School of electrical and information engineering \\ Beihua University \\ Jilin, China \\ E-mail:164085443@qq.com 47198245@qq.com
}

\begin{abstract}
Under the new situation, colleges and universities are faced with many problems, improving the quality of personnel training is the main problem of the current ordinary colleges and universities, but also the urgent requirement for talents in twenty-first Century. This paper discusses the innovation and entrepreneurship education in Colleges and universities of the shortcomings and deficiencies, to the cultivation of Applied Talents in the process of exploring the implementation path of innovation and entrepreneurship education, talent training program, specific measures are analyzed. On this basis, the author puts forward the specific research strategy of talent training mode reform, teacher training and construction, and project cooperation practice for electronic communication major.
\end{abstract}

Keywords-Innovation; Entrepreneurship; Strategy; Team building

\section{INTRODUCTION}

Chinese higher education after ten years of rapid development, during 1998 to 2013, the gross enrollment rate of higher education in China from $9.8 \%$ to $34.5 \%$, which indicates that China's higher education has been changed from elite education to mass education. In this context, colleges and universities are faced with new challenges to ensure and improve the quality of education and teaching. Local undergraduate colleges and universities are particularly prominent. In order to meet the new requirements of higher education massification of higher education is put forward, and comprehensively improve the quality of personnel training, the Ministry of education has issued a proposal to improve the quality of higher education some opinions and other documents, all colleges and universities also started the reform of education and teaching, cultivation mode reform has been deepened.

To implement the "Opinions of the State Council on further carrying out the employment and entrepreneurship work under the new situation" employment work under the new situation requires [1]: further strengthen on College Students' innovation and entrepreneurship support, inspire innovation and entrepreneurship students will improve college students' innovation and entrepreneurship curriculum system, complete with strong professional and vocational teachers, establish

Project supported by the Ministry of education of Jilin Province: Research project on teaching reform of vocational education and adult education in the Ministry of education of China (project approval number: 2016ZCY021) innovation system and change students' accumulation. Colleges and universities should be combined with the provincial situation and related policies, vigorously carry out the theme of education to live up to innovation and entrepreneurship activities, improve the innovation and entrepreneurship training teaching system, encourage teachers to lead students innovation and entrepreneurship.

\section{EASE OF USE DEFICIENCIES OF IMPLEMENTING INNOVATION AND ENTREPRENEURSHIP EDUCATION}

Local Undergraduate Colleges and universities, after more than ten years of engineering practice ability training mode of continuous exploration, in the students' practical ability has achieved remarkable results. However, this kind of fixed practice content, the student unified according to the practice instruction teacher's request, the engineering practice teaching pattern gradually exposes more and more questions [2]. First of all, with the development of electronic and information technology, The gap between the content of engineering practice and social needs is gradually widening, also cannot meet the new requirements of cultivating students' individual ability; secondly, the students are concentrated in the theory of the teaching mode of learning in the classroom, repeat in teaching practice. Which caused the students psychological resistance, students' enthusiasm for engineering practice and initiative is not high, which makes the engineering practice ability training effect; moreover, the engineering practice of fixed content and mode, greatly hindered the cultivation of students' creative consciousness and creative thinking and Practice instructors also have greater dependence, reform and innovation, is not conducive to the smooth development of innovation and entrepreneurship education.

Therefore, it is necessary to explore and study how to implement innovation and entrepreneurship education in the process of application-oriented talents training. 


\section{EXPLORATION ON THE PATH OF IMPLEMENTING INNOVATION AND ENTREPRENEURSHIP EDUCATION}

In accordance with the "public entrepreneurship, innovation", to cultivate students' innovative ability as the core, build entrepreneurial innovation and professional driven, project driven, platform driven, mechanism driven as the core working mode. Combining entrepreneurship education with teachers' scientific research and achievements transformation, combining with industry and enterprise, combining with professional education, career planning, social practice and graduation practice, and constantly improve the innovation and entrepreneurship education system, strengthen students' employment ability.

First of all, the training program of applied talents. Further revised, based on the characteristics of reflected application type, into the module of innovation and entrepreneurship education, At the beginning of the first semester of student enrollment, Combined with the characteristics of various specialties, the content of innovative entrepreneurship education is set up, stimulate innovation and entrepreneurship students with enthusiasm. The reform of teaching contents and teaching methods in the teaching process, application courses, redesign the teaching content and teaching syllabus, teaching content closely combining the technological development in the field of professional, innovation entrepreneurial thinking throughout the teaching process, in the course of experiment teaching content, cultivating innovative ability, increase the content of innovative, comprehensive design experiment; in practice teaching, cultivating students' innovative ability; carrying out innovation and entrepreneurship competition, found that students in the innovative thinking of flash points, making innovative entrepreneurial team, training and innovative incubator project; in the process of graduation design, a comprehensive summary of students in the learning process of four years in innovation, training students' ability of comprehensive application. Through the implementation of innovative ability, including innovation quality and consciousness, innovation incubator project, entrepreneurship training, innovative enterprises landing through the four years of progressive education, to cultivate innovative talents to information.

Secondly, the implementation steps, combined with various professional training direction and the characteristics of talent training, focusing on the selection of a group of a certain level of industrialization and the potential of the project, making the project implementation plan, project incubation; at the college level, The establishment of professional innovation practice base for the students sufficient, build a platform for students' innovation and Entrepreneurship; From the comprehensive evaluation of students, scholarships for students to encourage innovation and entrepreneurship mechanism; From the teacher assessment, evaluation, awards and other aspects, add the reward of College Students' innovative and entrepreneurial achievements, encourage more teachers to participate in the process of innovation and Entrepreneurship Education.

Finally, the specific measures, By the unified organization and coordination of the college, full investigation and demonstration, combined with professional construction projects, formulate application-oriented talents training program in line with the needs of College Students' innovation and entrepreneurship education; The curriculum system and practical training system of innovation and entrepreneurship education are constructed, and the innovation and entrepreneurship education of college students is closely integrated with the tutorial system of undergraduate students, and the corresponding reward mechanism is provided. The selection of some outstanding teachers and outstanding student pilot, through education, on the one hand the teachers can enhance their ability to fully realize the necessity of the construction of teachers, which showed a benign situation. On the other hand, the practice ability and innovation consciousness of students, to build a good platform for practice continue to promote this part of all aspects of students' ability; combined with quality education activities, the selection of some outstanding students with quality education competition of various professional training objectives, system design and practice ability, to make greater achievements in the competition; and joint enterprises, the establishment of entrepreneurial innovation incubation team, provide innovative ideas and direction by the enterprise, the establishment of engineering practice project, to achieve the transformation as the goal.

\section{SPECIFIC RESEARCH STRATEGIES OF TRANSFORMATION, INNOVATION AND ENTREPRENEURSHIP OF ELECTRONIC} COMMUNICATION SPECIALTY

Talent quality in twenty-first Century: basic learning skills; information literacy; innovative thinking ability; interpersonal communication and cooperation spirit; practical ability and so on. Therefore, high-quality talents for environmental adaptability, interpersonal skills, solid foundation, wide professional, innovative consciousness and creative ability and entrepreneurial spirit is the inevitable trend of the information age talent demand [3].

The innovation and Entrepreneurship of electronic communication specialty should be carried out in the following aspects:

\section{A. The reform of personnel training mode}

In order to achieve professional education can better serve the local economic and social development, the need to clear positioning application technology talents, do professional settings and local leading industries docking, docking training goals and needs of the industry, talent training and job requirements docking. The reform of the professional structure and curriculum system in order to meet the needs of economic development and industrial upgrading and technological progress, we must constantly adjust the specialty structure, improve the curriculum system, teaching contents and teaching methods, curriculum form can adapt to the need of the development of higher occupation education system.

At this time, we should solve the key problems: adjust the training program of information professionals. (1) to establish a professional and information industry enterprises in the integration of production and education innovation base as an opportunity to adjust the specialty of traditional teaching mode, realize the integration of education and engineering education, 
professional direction for guidance, taking the typical project industry as the main line, from the demand of project analysis, technical requirements, product target, knowledge into professional main courses. (2) Adjusting the training program of professionals in communication, electronics, information and computer science. Engineering quality based on innovation, base engineering quality training, engineering experience and other engineering quality education and school training program of classroom knowledge imparting academic education credit replacement, and truly implement the integration of production and education. (3) The implementation of school teaching and engineering education. The first grade university students, school education is mainly a larger proportion of the main learning of higher mathematics, English and other knowledge. Students in the form of a written report to complete their occupation planning and positioning, motive target formation in. Accounted for about $15 \%$ of the total hours, the proportion is small.

Sophomore, mainly circuit including electronics, computer hardware and software knowledge, engineering ability training, electronic design, software programming, etc., the proportion increased year by year, accounting for about $30 \%$ of the total hours. University of the third grade, students learn professional knowledge of electronic information and communication, to build the project experience and the embedded system in the platform to cultivate students, EDA hardware platform and network programming ability, the total hours accounted for about $50 \%$. Fourth grade, minor project management, engineering budget and other courses. Engineering education on students' Innovation Incubator project, entrepreneurial ability training, complete industry assistant engineer certification and certification engineer, which accounted for about $70 \%$ of the total hours, outstanding students will graduate with bachelor's degree and double card industry engineer certification, enterprises will be pre service training in the undergraduate education, employment, play advantage.

\section{B. Teaching staff training and construction}

Teaching staff training and construction [4]. Increase efforts to train Double qualified teachers, encourage young teachers to enterprises to carry out testing exercise, learn and understand the professional needs of enterprises, improve the relevant policies of enterprise technical personnel and highly skilled personnel to the University as part-time teachers, invite them to take practical courses. At present, most of the teachers are college graduates who just leave campus and enter the campus. They lack the experience of front-line enterprises. They have a deep brand of subject education. They haven't studied the teaching methods of application-oriented universities. Therefore, strengthening the cultivation of fulltime teachers' "double quality" is the guarantee of establishing a full-time teacher team with good quality and reasonable structure. Therefore, from the point of view of training mechanism, that is, from the work of human resources management department, we can carry out training mechanism construction from the following aspects.
1) Perfecting the training mechanism of "double qualified teachers"

To carry out the application oriented undergraduate education concept learning. Please come in, send out by way of learning the advanced application-oriented college education concept, learning method of teaching reform of applied undergraduate colleges, curriculum design and unit design of learning applied undergraduate course teaching. Carrying out post practice and horizontal technical service. The establishment of teacher practice system, use the vacation to encourage teachers to participate in the enterprise practice, and as one of the necessary conditions for the evaluation of professional titles Evaluation, job subsidies given, the industry's new technology, new technology and production, teaching closely, improve teachers' technical service ability and innovation ability, carry out horizontal research work. Professional teachers participate in and guide students in post practice, skills competition, the implementation of tutorial system. The teacher guides the students to practice, carry out internal and external training base and practice unit, through the organization to participate in various skills competition to guide teachers and students to participate in the practice of improving skills, and competition and practice activities designed to practice teaching project. Through the implementation of one to one tutorial system, teacher training is implemented in a planned way.

\section{Reforming the evaluation mechanism of teachers using the Template [5]}

According to the characteristics of application-oriented universities, the establishment of "Double qualified Teachers" title appraisal system: in the title of the assessment to the integration of teaching evaluation of teachers teaching ability and teaching reform of curriculum reform achievements, appropriate to reduce the research achievements in scientific research theoretical research papers reduce the proportion, improve the application requirements in the proportion in the evaluation of professional titles. Focus on the professional teaching reform achievement and professional skills results in the criteria in the evaluation of professional titles, get all pay attention to its teaching achievements, and guide students to participate in various skills contest, students' quality education achievements, support the number and level of its papers, for scientific research should assess its application level of scientific research, focus on the ability of enterprise regional economic cooperation service, carry out horizontal research into teaching reform of the school.

\section{Establishing and perfecting the incentive mechanism of "double qualified" teachers}

The construction of the salary and welfare system that conforms to the "double qualified qualified" teachers in Applied Undergraduate Colleges and universities is inclined to incline to the professional leaders and teaching team leaders in the income distribution, and to the "double qualified teachers". Schools should encourage teachers to study, especially to encourage teachers to participate in the practice of visiting engineer project, encourage teachers to participate in various learning and occupation skill training for teachers in applied undergraduate education practice and create a good atmosphere, 
and to develop policies to provide protection for the "Double qualified Teachers" development, to provide more room for growth as the "Double qualified Teachers" occupation development, promote teachers' development.

E. Form a special combination of the mixed team of teachers, improve the level of teaching and scientific research [6]

Cooperative enterprises stationed engineer and school to form a mixed team of teachers to carry out teaching and industry users and customer training, the professional training of "double teacher" team, improve the ability of scientific research application of full-time teachers, students and teachers can also participate in the enterprise landing project construction, speed up the implementation of Teachers to change the role of the engineer.

\section{F. Cooperation practice of industry university research project}

In order to better serve the local economic and social development, local colleges and universities should take the initiative to go out, understand the needs and problems of local enterprises, vigorously promote cooperation, adhere to the discipline development and the development of local interaction, discipline construction and growth of local enterprises and community interaction, teacher-student interaction, with local characteristics of the school characteristics. Optimize the training mode of industry, University and Research Institute, pay attention to the needs of local economic development, serve the local economy, and participate in the local economic construction according to the local characteristics. Due to the economic construction to keep rising in the state of electronic communication demands, the construction and development of innovative talents of high level technical team will serve as the main means to assist in the development of economic construction, the traditional industry and the electronic information technology integration, optimize the industrial structure, running mode of production with distinctive features.

\section{CONCLUSION}

In short, in the premise of a clear understanding of the current situation, the state, society, colleges and universities can cooperate with each other in a positive attitude, the spirit of serving the society, for the sake of the future of the principle, research to explore ways and means of entrepreneurship and innovation, I believe that in the near future, Innovation and Entrepreneurship education will be a new situation in front of the world.

\section{ACKNOWLEDGMENT}

Ma Xiping: Communication Engineering Specialty of School of electrical and information engineering, Beihua University.

\section{E-mail:476036346@qq.com}

Correspondence Author: Wang Zhongli, Institute of electrical and information engineering, Beihua University, electronic information and science and technology.

E-mail:164085443@qq.com47198245@qq.com

\section{REFERENCES}

[1] State Council, the State Council on promoting mass entrepreneurship and innovation of several policy measures [Z]. state, (2015) No. 32.

[2] Wen feng An. College students' innovation and entrepreneurship education on $[\mathrm{J}]$ education theory and practice, 2011, 5:12 - 15 .

[3] Xiao nian $\mathrm{Xu}$. Tech is innovation is a kind of superstition [J]. Corporate observer, 2016 (11): 18-19.

[4] A Nuo Zhao graceful. Education is not a hit of others [EB/OL]. (201707-06) [2017-08-02].

[5] Guofu Zheng. Research on the stage of professional development of "double qualified" teachers [D]. East China Normal University, 2010. (In Chinese)

[6] Tingting Gao. School enterprise cooperation secondary vocational school "double qualified" teacher team construction [D]. Yanbian University, 2015. (In Chinese) 